\title{
INTERPOLATION FORMULAS FOR COEFFICIENTS REDUCING THE STRENGTH OF STEEL AND ALUMINUM ALLOYS IN INCREASING TEMPERATURES
}

\begin{abstract}
M. GWÓŹDŹ́ 1
Heating of steel or structural aluminum alloys at a speed of 2 to $50 \mathrm{~K} / \mathrm{min}$ - characterizing the fire conditions - leads to a reduction in mechanical properties of the analyzed alloys. The limit of proportionality $f_{\mathrm{p}}$, real $f_{\mathrm{y}}$ and proof $f_{02}$ yield limit, breaking strength $f_{\mathrm{u}}$ and longitudinal limit of elasticity $E$ decrease as the temperature increases. Quantitative evaluation of the thermal conversion in strengths of structural alloys is published in Eurocodes 3 and 9, in the form of dimensionless graphs depicting reduction coefficients and selected (tabulated) discrete values of mechanical properties. The author's proposal for an analytical formulation of code curves describing thermal reduction of elasticity modulus and strengths of structural alloys recommended for an application in building structures is presented in this paper.
\end{abstract}

Keywords: steel, aluminum, fire, heating temperature, alloy strength, thermal reduction, mechanical properties

\section{PHYSiCAL MODEL OF AN ALLOY IN FIRE TEMPERATURE}

\subsection{FIRE MODEL}

Three different functions $\theta_{\mathrm{g}}(t)$, describing the interdependence between fire gas plume temperature $\theta_{\mathrm{g}}\left[{ }^{\circ} \mathrm{C}\right]$ in the vicinity of structural members and fire duration times $t$ [min] have been formulated in professional literature, among others in [1], [2], [7], [12], [19], [20], as well as in European code PN-EN 1991-1-2 [14]. The first function in the form of:

\footnotetext{
${ }^{1}$ Prof. dr hab. inż. Marian Gwóźdź, Institute for Building Materials and Structures, Faculty of Civil Engineering, Cracow University of Technology.
} 


$$
\theta_{\mathrm{g}}=20+345 \log _{10}(8 t+1)
$$

describes the so-called ISO standard fire, i.e. fire inside an enclosed compartment, fully developed. The second function describes external fire, i.e. pertaining to external structural components of a building - mainly the building façade. This function is defined as:

$$
\theta_{\mathrm{g}}=660\left(1-0,687 e^{-0,32 t}-0,313 e^{-3,8 t}\right)+20
$$

The third standard function describes the so-called hydrocarbon fire, i.e. a fire in which liquid or gas hydrocarbon fuels combust:

$$
\theta_{\mathrm{g}}=1080\left(1-0,325 e^{-0,167 t}-0,{ }^{675 e-2,5 t}\right)+20 .
$$

The fourth function, the so-called slow-burning curve, i defined in another European code PN-EN 13381 [17], as:

$$
\theta_{\mathrm{g}}=154 \sqrt[4]{t}+20 \text { for } t \leq 20
$$

$$
\theta_{\mathrm{g}}=345 \log [8(t-20)+1]+20 \text { for } t>20 .
$$

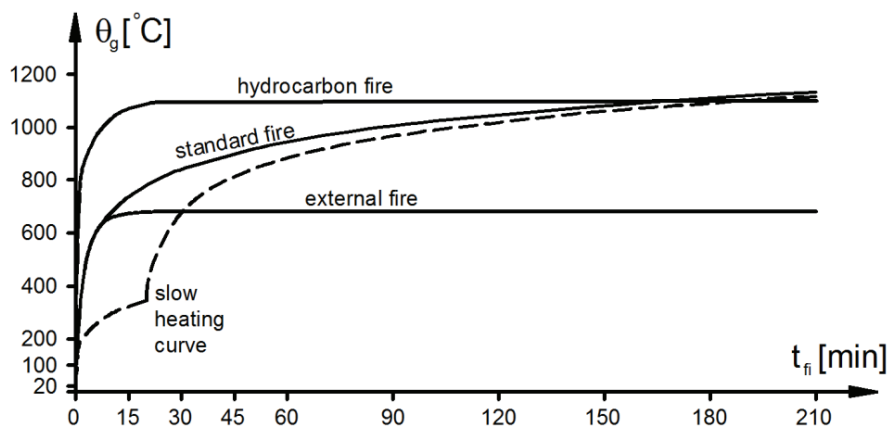

Fig. 1. Standard fire curves and the slow-burning curve

Standard fire curves according to formulas (1.1), (1.2), (1.3) and the slow-burning curve (1.4) are depicted in Fig. 1. These curves do not take into account the physical properties of the fire load in 
the building spaces nor the fire compartments. Since these are increasing functions, they do not represent the actual thermal influence of the fire - limited by the fire load in the building spaces and fire compartments. Multiple parameters determining the progress of actual fire affect the quantitative ratings, and the qualitative progress of such a fire is described by two typical phases: growth and cooling. The appropriate analytical formulas of a parametrical fire for several types of rooms (offices, hotel rooms, etc.) are listed in code PN-EN 1991-1-2. The development in numerical methods allows for modeling the progress of real fires in any type of room in a more realistic manner than the one represented by the above-enumerated standard and parametrical fire models (compare to, for instance [11]). Numerical models allow for an accurate forecasting of temperatures attained during the fire, the way in which the smoke plume falls and the fire spreads, time to full development and other physical phenomena. Two types of numerical models were developed specifically for the needs of fire analysis, namely the zone (compartment) and field (area) ones.

\subsection{MATERIAL MODELS IN FIRE TEMPERATURE}

Both the numerical fire models and the curves depicted in Fig. 1 indicate that a thermal exposure of unprotected metal components of even a few minutes in length may result in these elements being heated to temperatures of over $\theta>300^{\circ} \mathrm{C}$, comp. [4], [6], [8], [9], [10]. With a heating speed between 2 and $50 \mathrm{~K} / \mathrm{min}$, the mechanical properties and strains in structural steel with a definite yield limit $f_{\mathrm{y}, \theta}$ are described by the formulae:

$$
\begin{gathered}
\sigma=\varepsilon E_{\mathrm{a}, \theta} \text { for } \varepsilon \leq \varepsilon_{\mathrm{p}, \theta}, \\
\sigma=f_{\mathrm{p}, \theta}-c+\frac{b}{a} \sqrt{a^{2}-\left(\varepsilon_{\mathrm{y}, \theta}-\varepsilon\right)^{2}} \text { for } \varepsilon_{\mathrm{p}, \theta} \leq \varepsilon \leq \varepsilon_{\mathrm{y}, \theta}, \\
\sigma=f_{\mathrm{y}, \theta} \text { for } \varepsilon_{\mathrm{y}, \theta} \leq \varepsilon \leq \varepsilon_{\mathrm{t}, \theta}, \\
\sigma=f_{\mathrm{y}, \theta}\left[1-\frac{\varepsilon-\varepsilon_{\mathrm{t}, \theta}}{\varepsilon_{\mathrm{u}, \theta}-\varepsilon_{\mathrm{t}, \theta}}\right] \text { for } \varepsilon_{\mathrm{t}, \theta} \leq \varepsilon \leq \varepsilon_{\mathrm{u}, \theta},
\end{gathered}
$$

where:

$f_{\mathrm{y}, \theta}$ - yield limit of steel at temperature $\theta$, 
$f_{\mathrm{p}, \theta}$ - proportionality limit at temperature $\theta$,

$E_{\mathrm{a}, \theta}-$ modulus of linear elasticity,

$\varepsilon_{\mathrm{p}, \theta}$ - strain corresponding to the proportionality limit,

$\varepsilon_{\mathrm{y}, \theta}$ - strain corresponding to the yield limit,

$\mathcal{E}_{\mathrm{t}, \theta}$ - strain corresponding to the plastic flow of steel,

$\mathcal{E}_{\mathrm{u}, \theta}$ - limit strain.

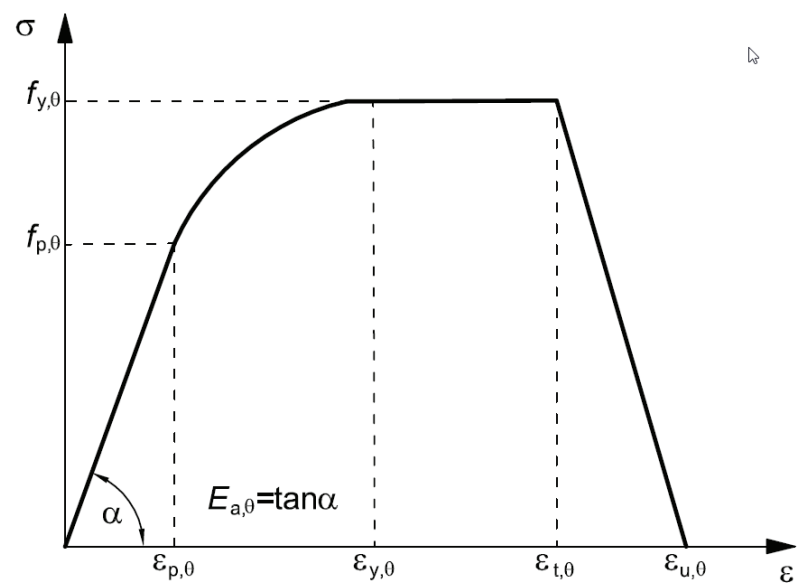

Fig. 2. Stress-strain relationship of carbon steel in fire temperatures

Functions according to the formulae (1.5) $\div(1.8)$ are depicted in Fig. 2, where the parameters $a, b$ and $c$ present in these formulae have the form of:

$$
\begin{gathered}
a=\sqrt{\left(\varepsilon_{\mathrm{y}, \theta}-\varepsilon_{\mathrm{p}, \theta}\right)\left(\varepsilon_{\mathrm{y}, \theta}-\varepsilon_{\mathrm{p}, \theta}+\frac{c}{E_{\mathrm{a}, \theta}}\right)}, \\
b=\sqrt{c\left(\varepsilon_{\mathrm{y}, \theta}-\varepsilon_{\mathrm{p}, \theta}\right) E_{\mathrm{a}, \theta}+c^{2}}, \\
c=\frac{\left(f_{\mathrm{y}, \theta}-f_{\mathrm{p}, \theta}\right)^{2}}{\left(\varepsilon_{\mathrm{y}, \theta}-\varepsilon_{p, \theta}\right) E_{\mathrm{a}, \theta}-2\left(f_{\mathrm{y}, \theta}-f_{\mathrm{p}, \theta}\right)} .
\end{gathered}
$$

The mechanical properties and strains in the stainless steel and aluminum alloys having a proof yield limit of $f_{02 \mathrm{p}, \theta}$ are described by: 


$$
\sigma=\frac{\varepsilon E_{\mathrm{a}}}{1+a \varepsilon^{\mathrm{b}}} \text { for } \varepsilon \leq \varepsilon_{\mathrm{c}, \theta}=0,003+\frac{f_{0,2 \mathrm{p}, \theta}}{E_{\mathrm{a}, \theta}},
$$

$$
\sigma=f_{0,2 \mathrm{p}, \theta}-\mathrm{e}+\frac{d}{c} \sqrt{c^{2}-\left(\varepsilon_{\mathrm{u}, \theta}-\varepsilon\right)^{2}}
$$

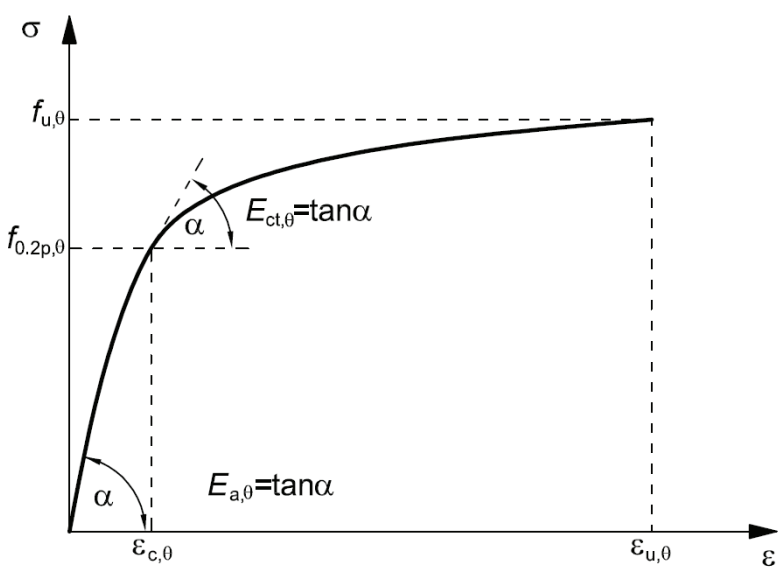

Fig. 3. Stress-strain relationship of stainless steel and aluminum alloys in fire temperatures

The functional relationship $\sigma-\varepsilon$ according to the formulae $(1.12) \div(1.13)$ is depicted in Fig. 3, where the parameters $a, b, c, d$ and $e$ present in these formulae have the form of:

$$
\begin{gathered}
a=\frac{E_{\mathrm{a}, \theta} \varepsilon_{\mathrm{c}, \theta}-f_{0,2 \mathrm{p}, \theta}}{f_{0,2 \mathrm{p}, \theta} \varepsilon_{\mathrm{c}, \theta}}, \\
b=\frac{\left(1-\varepsilon_{\mathrm{c}, \theta} \frac{E_{\mathrm{ct}, \theta}}{f_{0,2 \mathrm{p}, \theta}}\right) E_{\mathrm{a}, \theta} \varepsilon_{\mathrm{c}, \theta}}{\left(\frac{E_{\mathrm{a}, \theta} \varepsilon_{\mathrm{c}, \theta}}{f_{0,2 \mathrm{p}, \theta}}-1\right) f_{0,2 \mathrm{p}, \theta}}, \\
c=\sqrt{\left(\varepsilon_{\mathrm{u}, \theta}-\varepsilon_{\mathrm{c}, \theta}\right)\left(\varepsilon_{\mathrm{u}, \theta}-\varepsilon_{\mathrm{c}, \theta}+\frac{e}{E_{\mathrm{ct}, \theta}}\right)},
\end{gathered}
$$




$$
d=\sqrt{e\left(\varepsilon_{\mathrm{u}, \theta}-\varepsilon_{\mathrm{c}, \theta}\right) E_{\mathrm{ct}, \theta}+e^{2}},
$$

$$
e=\frac{\left(f_{\mathrm{u}, \theta}-f_{0,2 \mathrm{p}, \theta}\right)^{2}}{\left(\varepsilon_{\mathrm{u}, \theta}-\varepsilon_{c, \theta}\right) E_{\mathrm{ct}, \theta}-2\left(f_{\mathrm{u}, \theta}-f_{0,2 \mathrm{p}, \theta}\right)},
$$

where:

$f_{\mathrm{u}, \theta}$ - tensile strength at temperature $\theta$,

$f_{0,2 \mathrm{p}, \theta}$ - proof yield limit (corresponding to $\varepsilon=0,2 \%$ ) at temperature $\theta$,

$E_{\mathrm{ct}, \theta}$ - tangent modulus corresponding to the proof yield limit,

$\varepsilon_{\mathrm{p}, \theta}$ - strain corresponding to the proportionality limit,

$\varepsilon_{\mathrm{c}, \theta}$ - strain corresponding to the proof yield limit,

$\varepsilon_{\mathrm{u}, \theta}-$ limit strain.

\section{REDUCTION COEFFICIENTS OF MECHANICAL PROPERTIES}

The reduction coefficients are defined as the ratio of the mechanical property value at the raised temperature $\theta$ to the value of the analyzed property at a temperature of $20^{\circ} \mathrm{C}$. During the calculations regarding metal structures subjected to fire conditions the following are distinguished:

a) reduction coefficient for the proportionality limit $f_{\mathrm{p}}$ :

$$
k_{\mathrm{p}, \theta}=\frac{f_{\mathrm{p}, \theta}}{f_{\mathrm{p}}}
$$

b) reduction coefficient for the yield limit, real $f_{\mathrm{y}}$ or proof $f_{0,2}$ :

$$
k_{\mathrm{y}, \theta}=\frac{f_{\mathrm{y}, \theta}}{f_{\mathrm{y}}} \text { or } k_{\mathrm{o}, \theta}=\frac{f_{02, \theta}}{f_{02}}
$$

c) reduction coefficient for the tensile strength $f_{\mathrm{u}}$ :

$$
k_{\mathrm{u}, \theta}=\frac{f_{\mathrm{u}, \theta}}{f_{\mathrm{u}}}
$$


d) reduction coefficient for the linear elasticity modulus $E_{\mathrm{a}}$ :

$$
k_{\mathrm{E}, \theta}=\frac{E_{\mathrm{a}, \theta}}{E_{\mathrm{a}}} .
$$

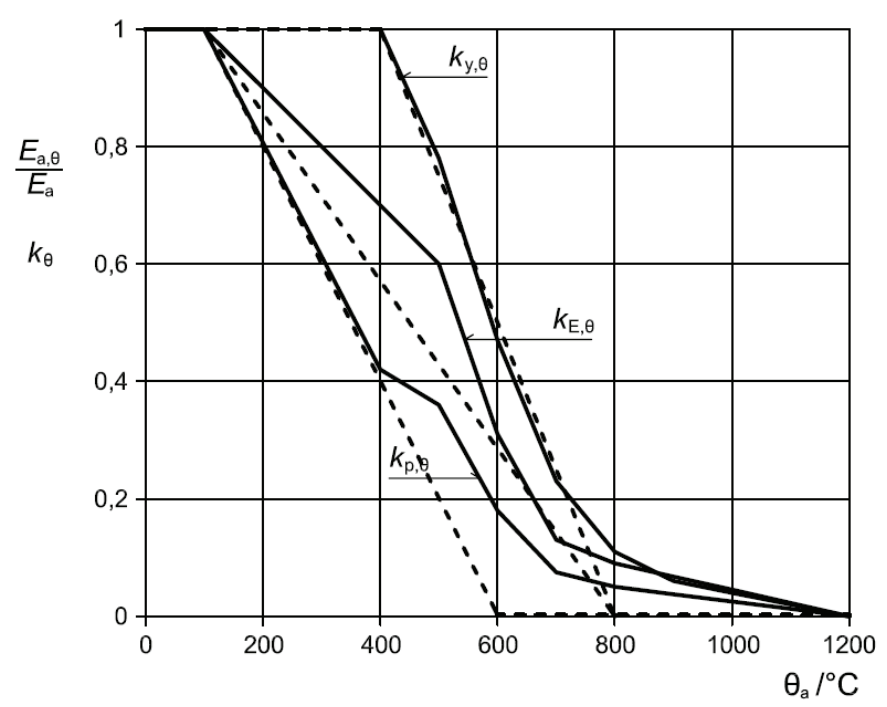

Fig. 4. Graphs of $\mathrm{k}_{\mathrm{p}^{-}}, \mathrm{k}_{\mathrm{y}^{-}}$, and $\mathrm{k}_{\mathrm{E}}$ reduction coefficients for steel products of class 1,2 and 3 made of carbon steel with distinct yield limit according to PN-EN 1993-1-1

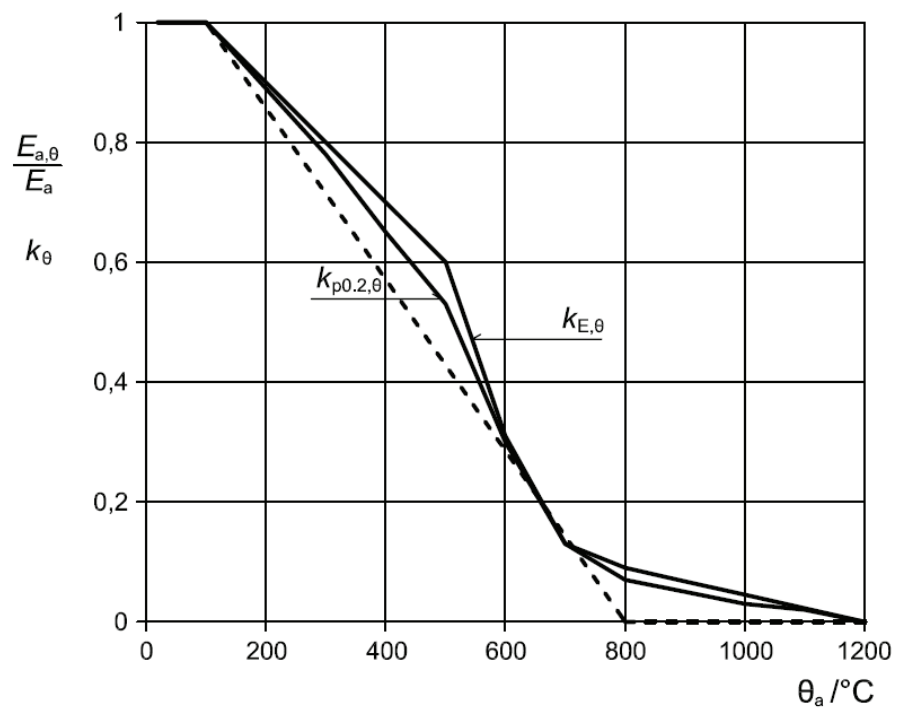

Fig.5. Reduction coefficients $\mathrm{k}_{02}$ and $\mathrm{k}_{\mathrm{E}}$ for steel products as above, class 4 


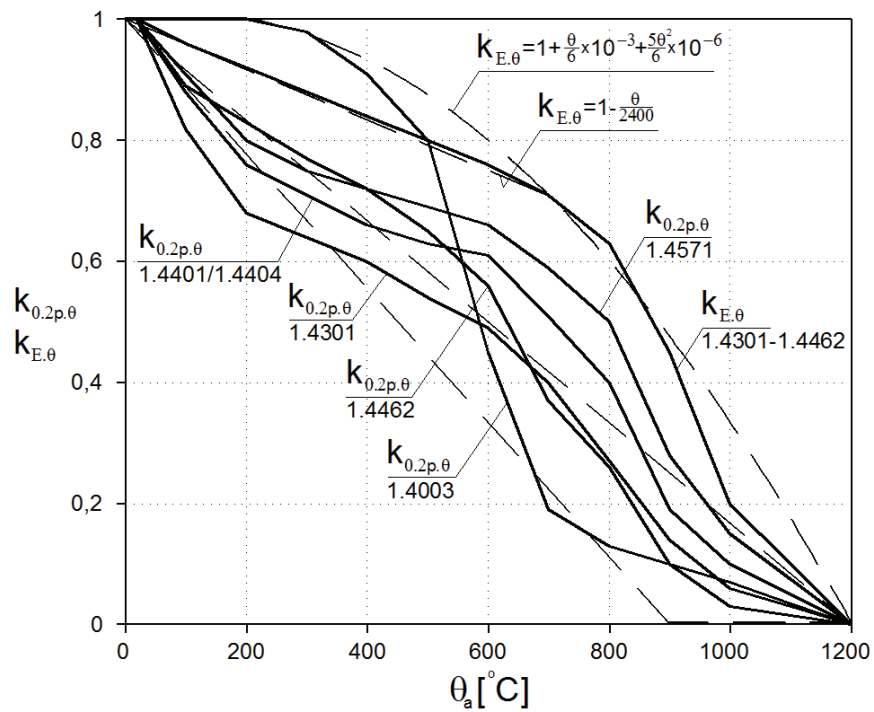

Fig. 6. Graphs of $\mathrm{k}_{02}$ and $\mathrm{k}_{\mathrm{E}}$ reduction coefficients for stainless steels according to PN-EN 1993-1-4

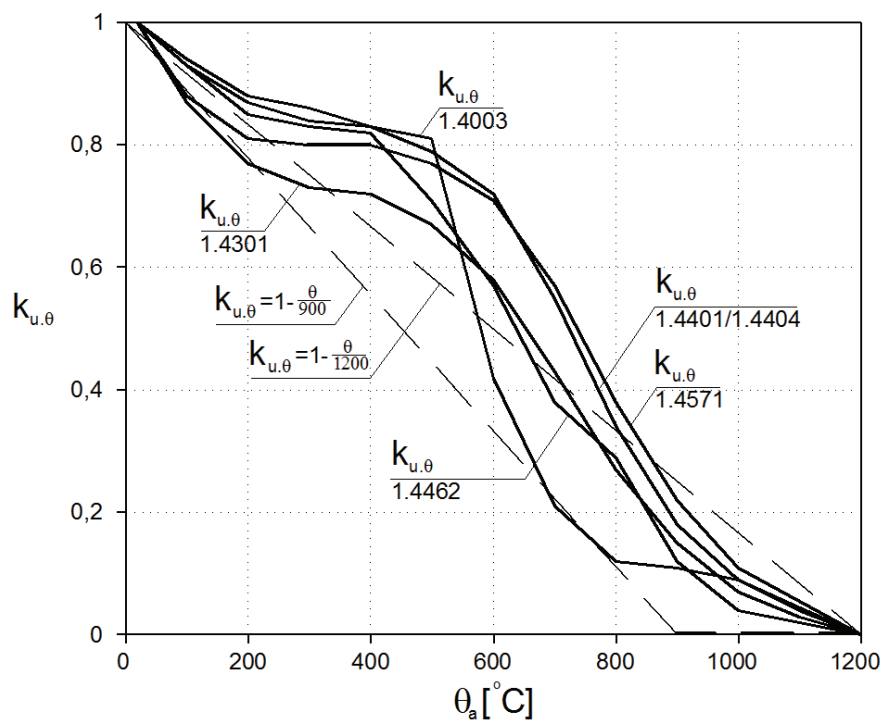

Fig. 7. Graphs of $k_{\mathrm{u}}$ reduction coefficients for stainless steels according to PN-EN 1993-1-4 


\subsection{CODE SPECIFICATIONS}

The graphical representation of reduction coefficients for mechanical properties of structural and stainless steel and aluminum alloys according to European codes [15] and [16] are depicted in the following figures (compare the continuous lines in Fig. 4 through Fig. 9). In Fig. 4 specifically, the appropriate graphs of $k_{\theta}$ are depicted for carbon steel (grades listed in PN-EN 1993-1-1), and for steel products with sections belonging to classes 1, 2 and 3, while in Fig. 5 for products with sections belonging to class 4 .

Figs. 6 and 7 depict the reduction coefficients for stainless steel (steel grades listed in code PNEN 1993-1-4), while Figs. 8 and 9 depict the same coefficients for structural aluminum alloys according to PN-EN 1999-1-1.

\subsection{INTERPOLATING FORMULAS}

The tabulated values of reduction coefficients $k_{\theta}$ for mechanical properties of steel and aluminum products listed in European codes [15] and [16], and graphs of these coefficients are useful only if individual analysis of structures either in real-life or in technological scenarios is considered. The empirical data presentation formula adopted in the codes is very inconvenient for application with commonly-used computer-supported statical and structural design tools.

These difficulties may be avoided if analytical functions are formulated, with parameters assigned so as to obtain compatibility with code data. In comparative calculations undertaken here, the usefulness of linear and nonlinear functions to interpolate the code data has been tested. Ultimately two functions proved to be sufficiently accurate and easy in practical application:

$$
\begin{gathered}
k_{\theta}=a-\frac{\theta}{\theta_{o}}, \\
k_{\theta}=d+c \theta-b \theta^{2},
\end{gathered}
$$

where $a, b, c$ and $d$-coefficients of interpolating formulas, specified in Table 2.1, $\theta_{\mathrm{o}}$ - alloy melting temperature, for which $k_{\theta}=0$ (for $a=1$ the point of intersection of the approximating line with the horizontal axis $\theta$ ). The interpolating formulas specified in Table 1 are denoted with dashed lines on Fig. 4 through Fig. 9, respectively. 


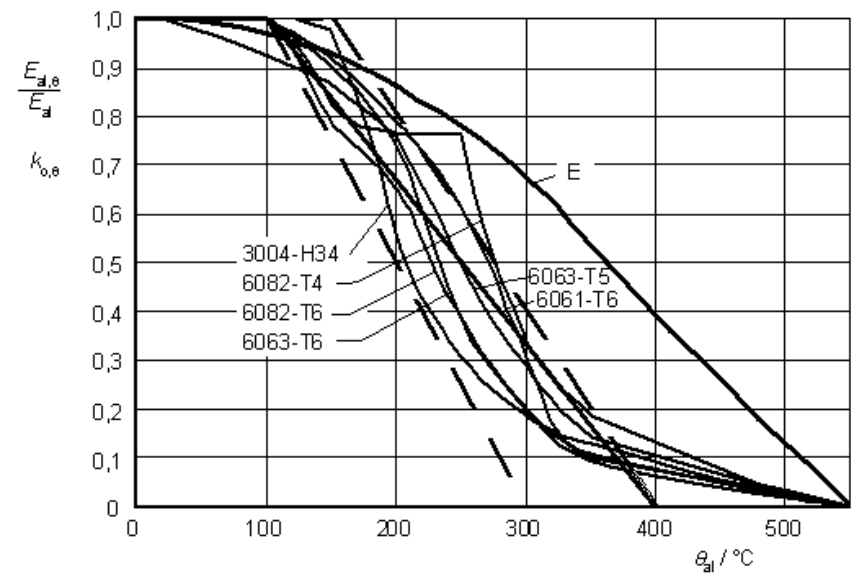

Fig. 8. Graphs of $k_{02}$ and $k_{\mathrm{E}}$ reduction coefficients for aluminum alloys of the 3004 and $6 \mathrm{xxx}$ series according to code PN-EN 1999-1-2

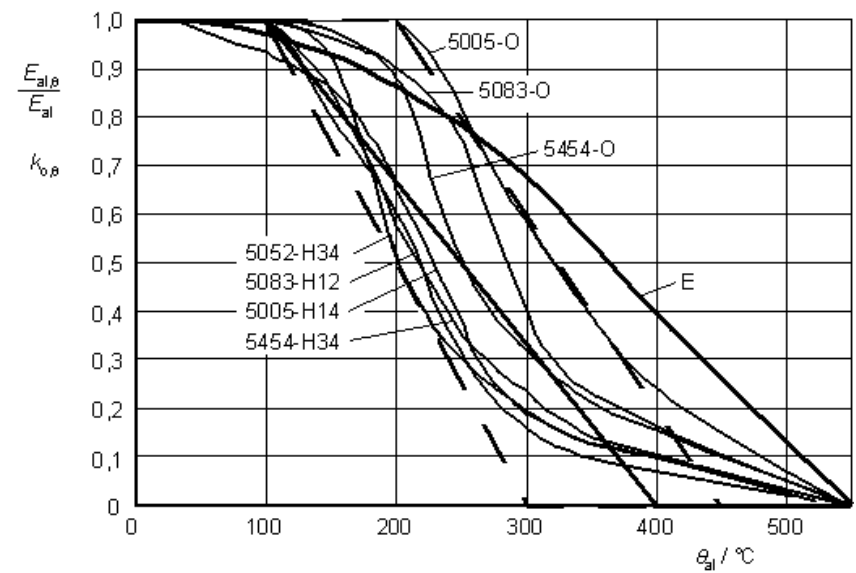

Fig. 9. Graphs of $k_{02}$ and $k_{\mathrm{E}}$ reduction coefficients for aluminum alloys of the $5 \mathrm{xxx}$ series according to code PN-EN 1999-1-2

\section{SUMMARY}

In the statical calculations of metal structures thermal actions are considered in two design scenarios. In the first the commonly persistent or transitional computational scenario, temperature has the character of technological actions, which may occur both in steel and aluminum structures. The second has an exceptional character, as it pertains to fire temperature, which occurs solely in steel structures (aluminum [13] and class 4 steel products are unsuitable for building structures 
Table 1. Interpolation formulas for reduction coefficients of steel and aluminum mechanical properties.

\begin{tabular}{|c|c|c|c|c|}
\hline \multicolumn{2}{|c|}{ Alloys } & \multicolumn{3}{|c|}{ Interpolation formulas for reduction coefficients } \\
\hline \multirow{3}{*}{$\begin{array}{l}\text { carbon } \\
\text { steel }\end{array}$} & $\begin{array}{l}\text { Class of } \\
\text { section }\end{array}$ & $k_{\mathrm{p}, \theta}$ & $k_{\mathrm{y}, \theta}$ & $k_{\mathrm{E}, \theta}$ \\
\hline & 1,2 i 3 & $\frac{6}{5}-\frac{\theta}{500}$ & $2-\frac{\theta}{400}$ & $\frac{8}{7}-\frac{\theta}{700}$ \\
\hline & 4 & - & \multicolumn{2}{|r|}{$\frac{8}{7}-\frac{\theta}{700}$} \\
\hline \multirow{3}{*}{$\begin{array}{c}\text { stainless } \\
\text { steel }\end{array}$} & battom & $k_{0,2 \mathrm{p}, \theta}$ & $k_{\mathrm{u}, \theta}$ & $k_{\mathrm{E}, \theta}$ \\
\hline & midding & \multicolumn{2}{|c|}{$1-\frac{\theta}{1200}$} & \multirow{2}{*}{$\begin{array}{c}1-\frac{\theta}{2400} \text { dla } \theta<700^{\circ} \mathrm{C} \text { lub } \\
1+\frac{\theta}{6} \cdot 10^{-3}-\frac{5 \theta^{2}}{6} \cdot 10^{-6} \text { dla } \theta<1200^{\circ} \mathrm{C}\end{array}$} \\
\hline & valuing & \multicolumn{2}{|c|}{$1-\frac{\theta}{900}$} & \\
\hline \multirow{9}{*}{$\begin{array}{l}\text { aluminum } \\
\text { alloys }\end{array}$} & series & battom & $k_{0, \theta}$ & $k_{\mathrm{E}, \theta}$ \\
\hline & & midding & $\frac{4}{3}-\frac{\theta}{300}$ & \multirow{8}{*}{$\frac{22}{21}-\frac{\theta}{1050}$ dla $\theta<200^{\circ} \mathrm{C}$} \\
\hline & $\begin{array}{l}3 \mathrm{xxx} \\
6 \mathrm{xxx}\end{array}$ & valuing & $\frac{3}{2}-\frac{\theta}{200}$ & \\
\hline & & overhead & $\frac{8}{-}-\theta$ & \\
\hline & & & $5 \overline{250}$ & \\
\hline & \multirow{4}{*}{$5 \mathrm{xxx}$} & battom & $\frac{4}{3}-\frac{\theta}{300}$ & \\
\hline & & valuing & $\frac{3}{-}-\frac{\theta}{2}$ & \\
\hline & & & 2200 & \\
\hline & & overhead & $\frac{9}{5}-\frac{\theta}{250}$ & \\
\hline
\end{tabular}

subject to potential fire risk). The subdivision of thermal actions cited above is quite important, since analytical formulas (2.5) and (2.6) should be rather precisely fitted to the empirical results gathered in Figs. 4 through 9. The principles of the good fit postulate in particular, within structure heating temperature range located between $20^{\circ} \mathrm{C}$ and $600^{\circ} \mathrm{C}$, should be satisfied in fire scenarios of cubature buildings made of carbon steel and having a definite yield limit with sections of class 1,2 , or 3. These simple approximations according to Table 1., and depicted with a dashed line in Fig. 4, show that this requirement is satisfied as the fitting error of line $k_{\mathrm{y}, \theta}$ does not exceed $2 \%$ and the two remaining lines $k_{\mathrm{p}, \theta}$ and $k_{\mathrm{E}, \theta}$ yield a safe estimate.

In the case of aluminum structures as well as of those made of stainless or carbon steel, the range of technological temperatures is usually narrower and falls within the limits of $70^{\circ} \mathrm{C}$ to $200^{\circ} \mathrm{C}$, thus the analytical formulas regarding reduction coefficients do not have to precisely fit the empirical 
data beyond these limits. The linear formulas for $k_{0,2 \mathrm{p}, \theta}, k_{\mathrm{u}, \theta^{-}}$, and $k_{\mathrm{o}, \theta}$, depicted in Fig. 5 through Fig. 9, are as such. Due to the proposed simple linearization of code data, one may individually fit the $a$ and $\theta_{\mathrm{o}}$ parameters to a given technological temperature of an analyzed structure.

The convex curves of reduction coefficient $k_{\mathrm{E}, \theta}$ for the elasticity limit of stainless steel and aluminum alloys, depicted in Fig. 6 through Fig. 9, may indicate the need for nonlinear interpolating formulas, for instance according to formula (2.6). The specifications of the parameters present in formula (2.6) for stainless steel (cf. Table 1) yield curve $k_{\mathrm{E}, \theta}$ depicted with a dashed line in Fig. 6 (curve is repeated in Fig. 7). The fitting error of this curve with respect to the code values does not exceed $10 \%$ and is acceptable in the evaluation of bar bearing capacity when subjected to fire (cf. for instance [3], [5], [18]).

In the case of technological temperatures, having a maximum value $\theta \leq 700^{\circ} \theta \mathrm{C}$, and acting on structures made of stainless steel, the linear formula yields a better fit, as the fitting error for straight-line parameters according to Table 1 does not exceed 1\% (a technological temperatures this high are possible in cases of certain structures, for instance in the shells of chimney stacks made of stainless steel with locally damaged internal lining).

Technological temperatures of aluminum structures usually do not exceed $100^{\circ} \mathrm{C}$, for instance in the shells of tanks used to store certain chemicals, thus for the purpose of statical analysis of such structures the linearization of the curve depicting reduction coefficient $k_{\mathrm{E}, \theta}$ performed in Table 1 is sufficient, as the fitting error of this straight line within the range of temperatures $\theta$ not exceeding $200^{\circ} \mathrm{C}$ does not exceed $2 \%$. 


\section{REFERENCES}

1. Abramowicz M., Gabryel Adamski R.: Fire safety of buildings. Part 1, , Main School of Fire Service, Warsaw, 2002 (in Polish).

2. Beard A. N., Fire models and design, Fire Safety Journal, 28 (1997), PP. 117- 138.

3. Biegus A.: Design of steel structures due to fire conditions according to Eurocodes, Izolacje, No. 2/2013, s. 20-28 (in Polish).

4. Bednarek Z., On determination of strains and thermal stresses in the fire conditions, Inżynieria i Budownictwo, No. 10/1994 (in Polish).

5. Boissonade N., Jaspart J.P., Muzeau J.P., Vilette M., New interaction formulae for beam-columns in Eurocode 3: the French-Belgian approach. Proceedings of III European Conference on Steel Structures Eurosteel 2002, Coimbra, Portugal, September 19-20, 2002.

6. Giżejowski M., Król P.: Design of steel members subjected to tension, compression and bending due to fire conditions according to PN-EN 1993-1-2. Inżynieria i Budownictwo, No. 9/2008, pp. 485-495 (in Polish).

7. Gwóźdź M., Suchodoła M: Fire safety of metal building structures. Printing office of Cracow University of Technology, (monograph, 8 publ. sheets), Cracow 2016 (in Polish).

8. Gwóźdź M., Tkaczyk A., Woźniczka P.: Rebuilding of fire damaged steel industrial halls. Bezpieczeństwo i Technika Pożarnicza, Centrum Naukowo Badawcze Ochrony Przeciwpożarowej, No. 4/2016 (in Polish).

9. Kosiorek M., Evaluation of fire resistance of existing steel structures after fire, Materials of XXXI All Poland Conference Warsztat Pracy Projektanta Konstrukcji, Szczyrk, 24-27.02.2016, pp. 531-576 (in Polish).

10. Kosiorek M., Fire safety of buildings. General Construction. Volume 2.: Building Physics, Chapter 9. Arkady, Warsaw 2005 (in Polish).

11. McGrattan K., Hostikka S., McDermott R., Floyd J., Weinschenk C., Overholt K.: Fire Dynamics Symulator User's Guide. NIST. Gaithersburg, Maryland, USA 2013.

12. Maślak M., Fire durability of steel bar structures. Printing office of Cracow University of Technology, Monograph No. 370, Cracow 2008 (in Polish).

13. Mazzolani F.M.: Aluminium alloy structures. Second edition E\&FN SPON an imprint of Chapman \& Hall, London 1994.

14. PN-EN 1991-1-2. Eurocode 1. Actions on structures. Part 1-2: General actions. Actions on structures in fire conditions. PWN Warsaw 2006 (in Polish).

15. PN-EN 1993-1-2. Eurocode 3. Design of steel structures. Part 1-2: General rules. Calculation of structures due to fire conditions. PKN Warsaw 2007 (in Polish).

16. PN-EN 1999-1-2. Eurocode 9. Design of aluminum structures. Part 1-2: Design of structures in the case of fire.. PKN Warsaw 2007 (in Polish).

17. PN-EN 13381. Test methods in order to determine the influence of protective measures on the fire resistance of structural elements. Part 1-8. PKN Warsaw 2013 (in Polish).

18. Skowroński W., Buckling fire endurance of steel columns, Journal of Structural Engineering, Vol. 119, No 6, 1993, pp.1712-1732.

19. Skowroński W., Fire safety theory of metal structures, PWN, Warsaw, 2001 (in Polish).

20. Turowski P., Sulik P.: Design of steel structures due to fire conditions according to Eurocode 3. Wydawnictwo Instytutu Techniki Budowlanej, Monograph 7,5 publ. sheets, Warsaw 2015 (in Polish). 


\section{LIST OF FIGURES AND TABLES:}

Fig. 1. Standard fire curves and the slow-burning curve

Rys. 1. Krzywe standardowe pożaru i krzywa powolnego spalania

Fig. 2. Stress-strain relationship of carbon steel in fire temperatures

Rys. 2. Zależność naprężenie-odkształcenie dla stali węglowej w temperaturze pożaru

Fig. 3. Stress-strain relationship of stainless steel and aluminum alloys in fire temperatures

Rys. 3. Zależność naprężenie-odkształcenie dla stali nierdzewnej i stopów aluminium w temperaturze pożaru

Fig. 4. Graphs of $\mathrm{k}_{\mathrm{p}}, \mathrm{k}_{\mathrm{y}}$, and $\mathrm{k}_{\mathrm{E}}$ reduction coefficients for steel products of class 1, 2 and 3 made of carbon steel with distinct yield limit according to PN-EN 1993-1-1

Rys. 4. Wykresy współczynników redukcyjnych $\mathrm{k}_{\mathrm{p}}, \mathrm{k}_{\mathrm{y}} \mathrm{i} \mathrm{k}_{\mathrm{E}}$ dla wyrobów hutniczych o przekrojach klasy 1,2 i 3, ze stali węglowej z wyraźną granicą plastyczności wg PN-EN 1993-1-1

Fig. 5. Reduction coefficients $\mathrm{k}_{02}$ and $\mathrm{k}_{\mathrm{E}}$ for steel products as above, class 4

Rys. 5. Współczynniki redukcyjne $\mathrm{k}_{02} \mathrm{i} \mathrm{k}_{\mathrm{E}}$ dla kształtowników stalowych jak wyżej klasy 4

Fig. 6. Graphs of $\mathrm{k}_{02}$ and $\mathrm{k}_{\mathrm{E}}$ reduction coefficients for stainless steels according to PN-EN 1993-1-4

Rys. 6. Wykresy współczynników redukcyjnych $\mathrm{k}_{02} \mathrm{i} \mathrm{k}_{\mathrm{E}}$ dla stali nierdzewnych wg PN-EN 1993-1-4

Fig. 7. Graphs of $k_{u}$ reduction coefficients for stainless steels according to PN-EN 1993-1-4

Rys. 7. Wykresy współczynników redukcyjnych $\mathrm{k}_{\mathrm{u}}$ dla stali nierdzewnych wg PN-EN 1993-1-4

Fig. 8. Graphs of $k_{02}$ and $k_{\mathrm{E}}$ reduction coefficients for aluminum alloys of the 3004 and $6 \mathrm{xxx}$ according to the code PN-EN 1999-1-2

Rys. 8. Wykresy współczynników redukcyjnych $k_{02}$ i $k_{\mathrm{E}}$ stopów aluminium serii 3004 i 6xxx wg normy PN-EN 1999-1-2

Fig. 9. Graphs of $k_{02}$ and $k_{\mathrm{E}}$ reduction coefficients for aluminum alloys of the $5 \mathrm{xxx}$ series according to the code PN-EN 1999-1-2

Rys. 9. Wykresy współczynników redukcyjnych $k_{02}$ i $k_{\mathrm{E}}$ stopów aluminium serii $5 \mathrm{xxx}$ wg normy PN-EN 1999-1-2

Table 1. Interpolation formulas for reduction coefficients of steel and aluminum mechanical properties Tabela 1. Formuły interpolacyjne współczynników redukcyjnych cech mechanicznych stali i aluminium 


\section{FORMULY INTERPOLACYJNE WSPÓLCZYNNIKÓW REDUKCYJNYCH WYTRZYMALOŚCI STALI I STOPÓW ALUMINIUM W PODWYŻSZONEJ TEMPERATURZE}

Słowa kluczowe: stal, aluminium, pożar, temperatura nagrzania, wytrzymałość stopu, redukcja termiczna, właściwości mechaniczne

\section{STRESZCZENIE:}

W obliczeniach statycznych konstrukcji metalowych oddziaływania temperatury uwzględnia się w dwóch sytuacjach projektowych. W pierwszej, zwykle trwałej lub przejściowej sytuacji obliczeniowej, temperatura ma charakter oddziaływań technologicznych, które mogą wystąpić zarówno w konstrukcjach stalowych jak i aluminiowych. Druga sytuacja ma charakter wyjątkowy, ponieważ dotyczy temperatury pożarowej, która może wystąpić tylko w budynkach o konstrukcji stalowej (wyroby hutnicze aluminiowe oraz stalowe klasy 4 nie nadają się na konstrukcje budynków zagrożonych potencjalnym pożarem). Przywołany podział oddziaływań temperatury ma dość istotne znaczenie z uwagi na wymaganą dokładność dopasowania formuł analitycznych do wyników empirycznych zestawionych w normach.

Nagrzewanie stali lub konstrukcyjnych stopów aluminium z szybkością od 2 do $50 \mathrm{~K} / \mathrm{min}$ - charakteryzującą warunki technologiczne i pożarowe, prowadzi do redukcji właściwości mechanicznych analizowanych stopów. Wraz ze wzrostem temperatury obniża się granica proporcjonalności $f_{\mathrm{p}}$, granica plastyczności: rzeczywistej $f_{\mathrm{y}}$ lub umownej $f_{02}$, wytrzymałość na rozerwanie $f_{u}$ oraz moduł sprężystości podłużnej $E$. Ocena ilościowa konwersji termicznej wytrzymałości stopów konstrukcyjnych została zamieszczona w Eurokodach 3 i 9 w formie wykresów bezwymiarowych współczynników redukcyjnych oraz wybranych wartości dyskretnych (tabelarycznych) właściwości mechanicznych. Współczynniki redukcyjne są definiowane jako stosunek wartości cechy mechanicznej w temperaturze podwyższonej $\theta$ do wartości badanej cechy w temperaturze $20^{\circ} \mathrm{C}$. W szczególności w obliczeniach konstrukcji metalowych w warunkach pożaru rozróżniamy:

a) współczynnik redukcyjny granicy proporcjonalności $f_{\mathrm{p}}$ :

$$
k_{\mathrm{p}, \theta}=\frac{f_{\mathrm{p}, \theta}}{f_{\mathrm{p}}},
$$

b) współczynnik redukcyjny granicy plastyczności rzeczywistej $f_{\mathrm{y}}$ lub umownej $f_{0,2}$ :

$$
k_{\mathrm{y}, \theta}=\frac{f_{\mathrm{y}, \theta}}{f_{\mathrm{y}}} \text { lub } k_{0, \theta}=\frac{f_{02, \theta}}{f_{02}},
$$

c) współczynnik redukcyjny wytrzymałości na rozciąganie $f_{\mathrm{u}}$ :

$$
k_{\mathrm{u}, \theta}=\frac{f_{\mathrm{u}, \theta}}{f_{\mathrm{u}}},
$$

d) współczynnik redukcyjny modułu sprężystości liniowej $E_{\mathrm{a}}$ :

$$
k_{\mathrm{E}, \theta}=\frac{E_{\mathrm{a}, \theta}}{E_{\mathrm{a}}} .
$$


W artykule przedstawiono propozycje własne analitycznego sformułowania normowych krzywych redukcji termicznej modułu sprężystości i wytrzymałości konstrukcyjnych stopów rekomendowanych na konstrukcje budowlane. W przeprowadzonych w pracy obliczeniach porównawczych analizowano przydatność do interpolacji danych normowych funkcji liniowych i nieliniowych. Ostatecznie wystarczająco dokładne i łatwe w zastosowaniach praktycznych okazały się dwie funkcje postaci:

$$
\begin{gathered}
k_{\theta}=a-\frac{\theta}{\theta_{o}}, \\
k_{\theta}=\mathrm{d}+c \theta-b \theta^{2},
\end{gathered}
$$

gdzie $a, b, c$ i $d$-współczynniki formuł interpolacyjnych wyspecyfikowane w tablicy 1 ,

$\theta_{\mathrm{o}}$ - umowna temperatura stopu, w której $k_{\theta}=0$ (dla $a=1$ punkt przecięcia prostej aproksymacyjnej z osią poziomą $\theta$ ).

\begin{tabular}{|c|c|c|c|c|}
\hline \multicolumn{2}{|c|}{ Stop } & \multicolumn{3}{|c|}{ Formuła interpolacyjna współczynników redukcyjnych } \\
\hline \multirow{5}{*}{$\begin{array}{c}\text { Stal } \\
\text { węglowa }\end{array}$} & $\begin{array}{c}\text { Przekroje } \\
\text { klasy }\end{array}$ & $k_{\mathrm{p}, \theta}$ & $k_{\mathrm{y}, \theta}$ & $k_{\mathrm{E}, \theta}$ \\
\hline & \multirow{2}{*}{1,2 i 3} & $6 \quad \theta$ & $2-\frac{\theta}{0}$ & $8 \quad \theta$ \\
\hline & & $5 \quad 500$ & 400 & $\overline{7}-\overline{700}$ \\
\hline & \multirow[t]{2}{*}{4} & \multirow[t]{2}{*}{ - } & \multirow{2}{*}{\multicolumn{2}{|c|}{$\frac{8}{7}-\frac{\theta}{700}$}} \\
\hline & & & & \\
\hline \multirow{4}{*}{$\begin{array}{l}\text { Stal } \\
\text { nierdzewna }\end{array}$} & oszacowanie & $k_{0,2 \mathrm{p}, \theta}$ & $k_{\mathrm{u}, \theta}$ & $k_{\mathrm{E}, \theta}$ \\
\hline & uśrednione & \multicolumn{2}{|c|}{$1-\frac{\theta}{2}$} & \multirow{2}{*}{$1-\frac{\theta}{2400}$ dla $\theta<700^{\circ} \mathrm{C}$ lub } \\
\hline & & \multicolumn{2}{|c|}{1200} & \\
\hline & dolne & \multicolumn{2}{|c|}{$1-\frac{\theta}{900}$} & $1+\frac{\theta}{6} \cdot 10^{-3}-\frac{5 \theta^{2}}{6} \cdot 10^{-6}$ dla $\theta<1200^{\circ} \mathrm{C}$ \\
\hline \multirow{13}{*}{$\begin{array}{l}\text { Stop } \\
\text { aluminium }\end{array}$} & seria & oszacowanie & $k_{0, \theta}$ & $k_{\mathrm{E}, \theta}$ \\
\hline & & uśrednione & $\underline{4}-\frac{\theta}{2}$ & \multirow{12}{*}{$\frac{22}{21}-\frac{\theta}{1050}$ dla $\theta<200^{\circ} \mathrm{C}$} \\
\hline & $3 \mathrm{xxx}$ & & $3 \quad 300$ & \\
\hline & $6 \mathrm{xxx}$ & dolne & $3 \quad \theta$ & \\
\hline & & & 2200 & \\
\hline & & górne & $8 \quad \theta$ & \\
\hline & & & $5 \quad \overline{250}$ & \\
\hline & \multirow{6}{*}{$5 \mathrm{xxx}$} & uśrednione & $4 \quad \theta$ & \\
\hline & & & $3 \quad 300$ & \\
\hline & & dolne & $3 \quad \theta$ & \\
\hline & & & 2200 & \\
\hline & & górne & $9 \quad \theta$ & \\
\hline & & & $5 \quad 250$ & \\
\hline
\end{tabular}

Tablica 1. Formuły interpolacyjne współczynników redukcyjnych cech mechanicznych stali i aluminium 